\title{
Britsko-francouzské vztahy v Indii 1787-1794 v zrcadle pramenư úřadu generálních guvernérů britské Indie
}

\section{Anglo-French Relations in India 1787-1794 in the Mirror of Governor-Generals of British India Sources}

\author{
Michal Wanner / michal.wanner@seznam.cz \\ Archivní správa MV ČR, Milady Horákové 133, Praha, CZ
}

\begin{abstract}
The study is devoted to the Anglo-French relations in India during the French Revolution, specifically in the years 1787-1794. The author in the introduction recapitulates historiography devoted to the impacts that the French Revolution had in European territorial possessions in India and the Indian Ocean. It refers to dominantly used to date the French sources stored in the National Archives in Paris, and especially the National Archives of Overseas Territories in Aix-en-Provence. On the basis of this analysis, and referring to sources from the office of Governor-Generals of the Presidency of Fort William in Calcutta untapped until now, he tries to reconstruct the Anglo-French relations in this area. In introduction he describes the political situation in India after the American War of Independence and the genesis of the French Company for India and China, the main partner of the British side in the observed period. On the basis of relevant documents analysis he defines two subsequent phases of mutual Anglo-French relationship: the period of friendship, business partnership and mutual assistance, which the French Revolution only disrupted to a limited extent (1786-1792) and the period of hostility after the French declared war on the United Kingdom and the Netherlands, which, however, for France in India brought about nothing but loss of important trading colonies (1793-1794).
\end{abstract}

\section{Keywords}

history of India, British-French relations in Asia, French Revolution in colonies, history of East India companies, British-French struggle for India, French colonial imperium in Asia, British colonial imperium in Asia, military history in the 18th century 


\section{Historiografie a využité prameny}

Francouzská revoluce patří k nejfrekventovanějším tématům světové historiografie. Pro její ohlasy v koloniích to však platí jen částečně. Tradičně velká pozornost byla věnována otázce zrušení a znovuzavedení otroctví v karibských koloniích a dějinám otrockého povstání a jeho potlačení na Haiti ${ }^{1}$. Vývoji v jiných francouzských koloniích, např. v koloniích v Indickém oceánu byla věnována o poznání menší pozornost, přestože k problematice lze nalézt práce francouzských, anglických i indických historiků od konce dvacátých let 20. století. Z doposud citovaných je nezbytné zmínit alespoň kapitolu věnovanou konci francouzského panství v Indii od Henryho Herberta Dodwella v Cambridgeských dějinách Indie z roku 1929², studie Marguerite V. Labernadie z třicátých let 20. století věnované vývoji v Pondichéry (dnešním Puduččéri) v letech 1790-1793 , a právně historické studie Pierra Lampuého z téhož období zkoumající právní postavení obyvatel francouzských kolonií ${ }^{4}$. Opomenout nelze rovněž příslušné kapitoly dějin francouzské Indie z pera Siby Pada Sena ${ }^{5}$ z padesátých a Rogera Glanchanta ${ }^{6}$ z šedesátých let 20. století zaměřené jak na sociální vývoj ve francouzských koloniích, tak francouzský spojenecký systém na indickém subkontinentu a jeho hybatele, francouzské dobrodruhy na dvorech indických knížat. Svůj význam v této souvislosti nepostrádají dodnes práce indického historika K. Rajayyana ze sedmdesátých let 20. století zasvěcená britské expanzi v dnešním Tamilnádu a vývoji francouzské alianční politiky v jižní Indii. ${ }^{7}$

Specifický, ale neopomenutelný charakter mají dodnes nepočetné studie věnované francouzské Společnosti pro Indie a Čínu (Compagnie des Indes et la Chine) vznikající téměř kontinuálně od třicátých let 20. století do prvního desetiletí 21. Století. Spojeny

1 Za všechny připomeňme jen několik titulů z posledního desetiletí: Delisle, Philippe: Catholicisme, esclavage et acculturation dans la Caraïbe francophone et en Guyane au XIXe siècle. Matoury 2006; Abolir l'esclavage: un réformisme à l'épreuve (France, Portugal, Suisse, XVIIIe-XIXe siècles). Ed. O. Pétré-Grenouilleau. Rennes 2008; Ehrard, Jean: Lumières et esclavage: l'esclavage colonial et l'opinion publique en France au XVIIIe siècle. Bruxelles 2008; Lapeyre, Françoise: Quand les voyageuses découvraient l'esclavage. Paris 2009; Blancpain, François: Étienne de Polverel: libérateur des esclaves de Saint-Domingue. Bécherel 2010; Oudin-Bastide, Caroline: L'effroi et la terreur: esclavage, poison et sorcellerie aux Antilles. Paris 2013; Chivallon, Christine: L'esclavage, du souvenir à la mémoire: contribution à une anthropologie de la Caraïbe. Paris 2013; Grenouilleau, Olivier: Qu'est-ce que l'esclavage?: une histoire globale. Paris 2014; Larcher, Silyane: L'autre citoyen: l'idéal républicain et les Antilles après l'esclavage. Paris 2014.

2 Dodwell, Henry Herbert: The Exclusion of French, 1784-1815, in: The Cambridge History of India. Vol. V. British India 1497-1757. Ed. H. H. Dodwell. Cambridge 1929, s. 323-332.

3 Labernadie, Marquerite V.: La Révolution et les Etablissements Français dans l'Inde (1790-1793), d'après les archives de Pondichéry, des notes et des correspondances inédites. Paris 1930; Táž: Le Vieux Pondichéry (1674-1815). Pondichéry 1936.

4 Lampué, Pierre: Le régime constitutionnel des colonies françaises. In : Annales du droit et des sciences sociales IV, 1934, s. 233-244.

5 Sen, Siba Pada: The French in India (1765-1816). Calcutta 1958.

6 Glanchant, Roger: Histoire de l'Inde des français. Paris 1965.

7 Rajayyan, K..: South Indian Rebellion, the First War of Independence (1800-1801). Mysore 1971; Týž: History of Madurai (1736-1801). Madurai 1974. 
jsou především se skupinou historiků spjatou s univerzitami v Angers a Lorientu a Muzeem Společnosti Indií v tomto městě. ${ }^{8}$

Vedle tohoto proudu nelze opominout obecněji zaměřenou studii novináře a militantního antikolonialisty Yvese Benota (vl. jménem Édouarda Helmana ) ${ }^{9}$ z konce osmdesátých let 20. století popisující ukončení otroctví a konec francouzských kolonií ve světě, ani práci Jeana Batbedata věnovanou činnosti francouzských dobrodruhů ve službách indických knížat ${ }^{10}$.

Mimořádný význam v bádání o dopadech francouzské revoluce v Indii měly studie z konce osmdesátých a počátku devadesátých 20. století spjaté s činností Mezinárodní historické asociace pro Indický oceán. Patří mezi ně především výsledky mezinárodní konference konané v Saint-Denis de la Reunion v roce 1986 mapující historické a kulturní vztahy Francie a indických vládců od 17. století. ${ }^{11}$ Zásadní zlom v bádání pak představovalo kolokvium konané v ř́ínu 1990 v Saint-Pierre de la Réunion organizované opět Mezinárodní historickou asociací pro Indický oceán. Výsledky tohoto setkání byly publikovány ve sborníku editovaném Claudem Wanquetem a Benôitem Jullienem publikovaném v Paříži v roce $1996 .{ }^{12}$ V něm byly shromážděny klíčové studie pokrývající vývoj ve francouzských koloniích v letech 1750-1803, následné dozvuky revolučních událostí a jejich druhý život až do roku 1914. Popsaný sborník se týkal jak vývoje na francouzských Maskarénách, Madagaskaru, Komorách a Seychelách, tak v koloniích na indickém subkontinentu, který je v centru pozornosti autora tohoto článku.

Výše uvedené studie týkající se indických osad lze rozdělit podle zaměření na následující oblasti. Část autorů popisuje revoluční události ve francouzských koloniích, především v centru francouzských kolonií v Pondichéry na Koromandelském pobřeží. ${ }^{13}$ Tento proud se soustřed'uje primárně na otázky mezirasových a sociálních vztahů. Další směry

8 Conan, Jules: La dernière compagnie française des Indes (1785-1875). Paris s. d. (1942); Dermigny, Louis: Cargaisons indiennes. Solier et Cie 1781-1793. 2 vol. Paris 1959-1960; Eude, Michel: Une interprétation non-mathiézienne de l'affaire de la Compagnie des Indes. Annales historiques de la Révolution française, No 244, avril-juin 1981, s. 239-261; Le Bouëdec, Gérard: Le port et l'arsenal de Lorient de la Compagnie des Indes à la marine cuirssé : une reconversion réussie: XVIII ${ }^{e}$-XIX ${ }^{e}$ siècles. 4 vol. Paris 1994; Morineau, Michel: Les Grandes Compagnies des Indes orientales. Paris 1999; Haudrère, Philippe - Le Bouëdec, Gérard: Les Compagnies des Indes. Rennes 1999; Favier, René : Les Européens et les Indes orientales au XVIII siècle; aspects maritimes, commerciaux et coloniaux. Ophrys 2000; Marzagalli, Silvia - Bonin, Hubert: Négoce, ports et océans, $X V^{e}$-XIX $X^{e}$ siècles. Mélanges offerts à Paul Butel. Pessac 2000; Mézin, Louis - Le Bouëdec, Gérard - Haudrère, Philippe: Les Compagnies des Indes. Rennes 2005; Le Bouëdec, Gérard: Les Compagnies françaises des Indes et l'économie du privilège. Francfort 2013; Claeys, Thierry - Le Bouëdec, Gérard: Commerce Libre et Compagnie de Calonne. In: Les Compagnies des Indes. Ed. R. Estienne. Paris 2013, s. 83.

9 Benot, Yves: La révolution française et la fin des colonies. Paris 1990.

10 Batbedat, Jean: In the Service of Indian Princes. In: The French in India: From Diamond Traders to Sanskrit Scholars. Ed. V. Rose. Bombay 1990, s. 96-121.

11 Les relations historiques et culturelles entre la France et l'Inde : XVIIe-XXe siècles = Historical and cultural relations between France and India : XVIIth-XXth centuries. Saint-Denis de la Reunion 1987.

12 Révolution Francaise et Océan Indién: prémices, héritages et déviances. Eds. C. Wanquet- B. Jullian. Paris 1996.

13 Taffin, Dominique: Citoyens et Malabars à Pondichéry pendant la révolution française (1750-1793). Tamtéž, s. 235-248. 
se snaží podchytit vliv francouzské revoluce v jiných evropských koloniích v Indii ${ }^{14}$ a dopady revoluce na dosavadní francouzskou alianční politiku mezi indickými knížaty a tím i na celkovou politickou situaci na indickém subkontinentu. ${ }^{15}$ Specifický, ale významný přínos znamenaly studie M. Gobalakichenana věnované tamilskému rukopisu známému jako „Journal de Viranaicker“ popisující události v Pondichéry v letech 1778-179216 a jeho studie o činnosti Tamilů ve francouzských koloniích v období revoluce ${ }^{17}$.

$\mathrm{Z}$ výše uvedeného přehledu je patrné, že dosavadní literatura se soustřed'ovala na politický a sociální vývoj v indických faktoriích, především v centru francouzských držav v Indii a na nepočetné dopady, které přinesla francouzská revoluce do sféry vztahů mezi státy na indickém subkontinentu, a to s jednoznačnou preferencí jižní Indie. Vývoj v jiných významných centrech francouzské moci v Indii zůstal opomenut.

Z hlediska pramenné základny jednoznačně dominovalo využití dokumentů uložených dnes v Archives Nationales d'Outre-Mer v Aix-en-Provence (ANOM), v Archives National (AN) v Paříži, v menším množství pak archiválie z Records Centre v Puduččéri či již zmíněný „Veranaikerův deník“ v tamilštině ${ }^{18}$.

Prameny z provenience jiných evropských obchodních společností nebyly dosud prakticky využity. Tato studie se pokouší situaci alespoň částečně zacelit tím, že za základ pro studium pojala dokumenty kanceláře úřadu generálního guvernéra prezidencie Fort William v Kalkatě. Tyto dokumenty ukazují vývoj v Čandarnagaru a dalších francouzských faktoriích v Bengálsku, ale i britský vztah vůči francouzské Společnosti pro východní Indie a Čínu a Francouzům v Indii vůbec. Autor použil pro práci na tomto příspěvku 16. a 17. svazku edice dokumentů řady Fort-William India House Correspondence vydávané Indickým Národním archivem v Dillí. ${ }^{19}$

\section{Politická situace v Indii po válce o nezávislost USA}

Vztahy mezi evropskými velmocemi v Indii v období před vypuknutím velké francouzské revoluce vycházely ze stavu, který byl výsledkem války o americkou nezávislost (17761783). Tento stav kodifikovala mírová smlouva s Francií podepsaná 20. ledna 1783 v Paříži a formalizovaná 3. září 1783 ve Versailles. Francie se v ní zřekla podpory maisúrského sultána a obdržela zpět všechny své základny obsazené během konfliktu Brity (Balasúr,

14 Carreira, Ernestine: Les implication française dans la conspiration de 1787 à Goa: mythe a réalités. Tamtéž, s. 211-220.

15 Viakuntham, Yallam Palli: The French Revolution and the Late 18th Century Colonial South India. Tamtéž, s. 249-258..

16 Gobalakichenane, M.: La révolution de Pondichéry d'aprés Viranaicker II. Tamtéž, s. 221-234.

17 Gobalakichenane, M.: La Revolution Française des Tamouls de Pondichery (1790-1793). Chennai 2014.

18 Gobalakichenane, M.: Irandam Viranaiker Natkurippu (1778-1792). Chennai 1992.

19 Fort William-India House Correspondence and Other Contemporary Papers Relating Thereto (Foreign, Political and Secret), Vol. XVII: 1792-1795. Ed. V. J. Tarapoverala. Delhi 1955. Dále FWIHC, Vol. XVII; Fort-William-India House Correspondence and Other Contemporary Papers Relating Thereto (Foreign, Secret and Political), Vol. XVI: 1787-1791. Ed. S. H. Askari. Delhi 1976. Dále FWIHC, Vol. XVI. 
Kásimbázár, Jugdii, Dháku, Patnu, Mačilípatnam, Kalikat (dnešní Kóžikkót) a Surat). Francii se však nepodařilo restaurovat vliv, kterým v Indii disponovala až do porážky v sedmileté válce. Nedosáhla ani práva opevňovat své osady. ${ }^{20}$ Obnovení mocenských pozic v Indii však nebyla cílem velitelů francouzské pozemní armády, spíše chtěli vázat s pomocí indických spojenců část anglických pozemních i námořních sil daleko od klíčových bojišt v Evropě a Americe. Válka na vzdáleném bojišti navíc vyčerpala francouzské síly. Francouzi svou porážkou de facto podpořili další britskou teritoriální expanzi v Indii. Francouzské kolonie se po válce opět soustředily na obchod, i když i nadále udržovaly styk s potenciálními nepřáteli Britů, včetně sultána Típúa. ${ }^{21}$

Válka připravila indická knížata o významného evropského spojence ochotného budovat rozsáhlou protianglickou koalici. Rovněž ukázala neschopnost indických knížat společně vystoupit proti vzrůstající britské moci pohlcující postupně nástupnické útvary rozpadající se Mughalské ř́šse. Technologická převaha anglických armád opírající se o dokonalou kontrolu námořních cest ještě zesílila, Francouzi jako dodavatelé evropských technologií indickým armádám vypadli ze hry. Cesta k další britské expanzi v Indii se tak ještě více otevřela. Indie roku 1784 ztratila schopnost čelit anglické dominanci.

Ještě více byly otřeseny pozice Nizozemců. Zatímco mezi Francouzi a Brity byl nastolen status quo ante bellum, nizozemská Spojená východoindická společnost (Verenigde Oostindische Compagnie) na základě předběžné mírové smlouvy z 2. září 1783 v Pařízii, stvrzené 20. května 1784 tamtéž, ztratila př́stav Nágapattanam, který zůstal v britských rukou. ${ }^{22}$ Nizozemsko tak přišlo o město s 277 vesnicemi, středisko nizozemské správy, textilní výroby i soukromého obchodu. Novým centrem nizozemských kolonií na Koromandelském pobřeží se stal Pulikát. Výstavba tohoto centra spolykala většinu zisků z prodeje místních látek a udržování řady faktorií bylo natolik neefektivní, že byly postupně zavírány. ${ }^{23}$ Prohra ve válce o americkou nezávislost rovněž potvrdila úpadek nizozemské moci v Indickém oceánu a byla velkou ranou pro upadající Spojenou východoindickou společnost. Nizozemská společnost se ve válce dostala se do vleklé finanční krize, která vedla až $\mathrm{k}$ jejímu zániku. ${ }^{24}$

Anglická Východoindická společnost pod vedením generálního guvernéra Warrena Hastingse dokázala uhájit pozice získané v období sedmileté války a v následujícím období. Vojenská i námořní moc společnosti posílily. Cena za vítězství však byla vysoká. Zisky z Bengálska byly spotřebovány na výstavbu sipáhijských armád v Indii, nikoli do zvýšeného importu zboží do Evropy. To vedlo k těžké finanční krizi společnosti, která vyvrcholila v Británii v roce $1772 .{ }^{25}$ Tato krize poskytla velkou př́ležitost pro britský stát vyčerpaný

20 Jenkinson, Ch.: A Collection of All the Treaties of Peace, Alliance and Commerce Between Great Britain and Other Powers. Vol. 3. London 1785, s. 334-342, články 13-16 týkající se francouzské Indie, s. 339-340.

21 Das, Sudipta: The French Imperialism in India, 1763-1783. New York 1992, s. 287.

22 Jenkinson, Ch.: A Collection of All the Treaties of Peace, s. 420-430

23 Prakash, Om: The New Cambridge History of India II/5: European Commercial Enterprise in Pre-Colonial India. Cambridge 1998, s. 172-3, 233, 300.

24 Israel, Jonathan: The Dutch Republic: Its Rise, Greatness and Fall, 1467-1806, Oxford 1995, s. 1097.

25 K finanční krizi Východoinické společnosti podrobně Wanner, Michal: Zrozeni impéria: Východoindická společnost a britský stát (1600-1773). Praha 2003, s. 198-208. 
válkou a oslabený ztrátou 13 amerických kolonií. Vždyt obchod s Indií představoval šestinu britského národního příjmu. Britský parlament zřídil vyšetřovací komisi, jejíž podrobné zprávy z let 1782-1783 probudily britskou veřejnost a přiměly vládu jednat. Řešení bylo nakonec nalezeno v Pittově indickém zákonu z roku 1784. Zákon zřizoval šestičlenný Kontrolní výbor, složený ze dvou př́slušníků kabinetu a 4 členů Tajné rady, který měl „dohližet, ř́dit a kontrolovat“ teritoria společnosti. ${ }^{26} \mathrm{~V}$ praxi však spíše dohlížel na civilní, vojenské a daňové záležitosti Východoindické společnosti. Byla tak predestinována společná správa Indie orgány koruny a Východoindické společnosti, přičemž koruna zůstala nejvyšší autoritou ve všech rozhodnutích. Generální guvernér Indie byl jmenován korunou a byly posíleny jeho pravomoci v oblasti války, diplomacie a daní, a to na úkor guvernérů v Madrásu a Bombaji. Obdržel dokonce právo veta vůči rozhodnutím direktoria Východoindické společnosti. ${ }^{27}$ Tato norma zastavila korupci prováděnou zaměstnanci společnosti a zvýšila pravomoci generálního guvernéra.

\section{Nová francouzská východoindická společnost}

Britským partnerem na francouzské straně se v tomto období stalo nové obchodní těleso - Společnost pro Indie a Čínu (Compagnie des Indes at la Chine), které po šestnáctiletém období, kdy byl obchod mezi Francií a zeměmi východně od mysu Dobré naděje umožněn všem francouzským obchodníkům, převzalo znovu monopol na tento obchod. ${ }^{28}$ Volání po nové monopolní společnosti pro obchod s východními Indiemi odráželo slabost, kterou jednotlivý francouzští obchodníci pocitovali vưči Britům v Indii. Tento fakt se odrazil v pojednání, které v roce 1783 na podnět generálního kontrolora financí Charlese Alexandra de Calonne vytvořil finančník a rejdař Jacques-Alexandre Gourlande. ${ }^{29}$ Zatímco Charles Gravier hrabě de Vergenes viděl jako diplomat ve společnosti především nástroj pro boj s Brity v této oblasti a odmítal jakákoli řešení podřizující společnost Britům, státní tajemník námořnictva Charles Eugène Gabriel de La Croix, markýz de Castries postupoval realističtěji. V roce 1783 pověřil Gourlanda a Pierra Berniera jednáním s anglickou Východoindickou společností prostřednictvím londýnské banky ovládané Samuelem Cholletem a Jamesem Bourdierem. William Pitt, který nastoupil do úřadu britského premiéra v roce 1783, se vyjádřil ve prospěch projektu, který chápal jako prostředek k redukci moci jednotlivých navábů a nástroj $\mathrm{k}$ podpoře obchodu anglické Východoindické společnosti. V souladu s výsledky jednání se generálnímu kontrolorovi financí de Calonnovi podařilo v prosinci 1784 smírit Gourlandovu skupinu a skupinu bankéřů kolem Emmanuela Hallera, jednoho

26 Keay, John: The Honourable Company: A History of the English East India Company. Basingstoke 1991, s. 390.

27 Furber, Holden: The East India Directors in 1784. Journal of Modern History 5, 1933, s. 479-495.

28 Trvalá společnost Indií (Compagnie Perpétuelle des Indes), která předcházela této společnosti, přišla o monopol vládním dekretem z 8. srpna 1769. Akcionáři poté předali veškerý majetek společnosti státu a ediktem z ledna 1770 obdrželi za tento majetek odškodněni. Srv. Haudrère, Philippe: La Compagnie française des Indes au XVIIIe siècle. Vol. 2. Paris 2005, s. 789-816.

29 Haudrère, Philippe: Quelques aspects du commerce entre la France et l'Asie à la fin du XVIIIe siécle 1765-1793. In: Révolution Francaise et Océan Indién, s. 31-37, odkaz s. 35. 
z podílníků banky Girardet a Haller, která byla spjata s předchozím generálním kontrolorem financí Jacquesem Neckerem (ve funkci 1776-1781). Přidala se i finanční skupina z Grenoblu v čele Augustinem Périerem, chráněncem Castriesovým. Do nové společnosti vstoupila i řada ředitelů původní Trvalé společnosti Indií (Compagnie Perpétuelle des Indes) suspendované v roce 1769. Mezi podílníky pronikla i rodina vlivných bretaňských obchodníků z Lorientu, bratří Bérardů, v čele s Thomasem-Simonem Bérardem, blízkým pařížské bance Sabatier a Desprez, švýcarský bankéř Isaac Panchaud (zakladatel diskontního fondu a blízký poradce Calonna) a Skot William Herries. ${ }^{30}$

Společnost byla založena téměř v tajnosti dekretem Královské státní rady z 3. června 1785. Disponovala kapitálem ve výši dvaceti milionů livrů a privilegiem umožňujícím monopolní obchod východně od mysu Dobré naděje potvrzený rozhodnutím rady ze dne 21. září 1786. Monopol se nevztahoval na souostroví Maskarény, tedy přístavy na ostrovech Isle de France (Mauritius) a Isle de Bourbon (Reunion). Ty zůstaly př́istupné všem francouzským lodím. ${ }^{31}$

Společnost sídlila v budově Hôtel de Massiac, bývalém sídle banky Jabach na Place des Victoires v Paříži. Převzala budovy, obchody a dílny předchozí Trvalé společnosti Indií v Lorientu a Marseille. Lorient se stal domovským př́ístavem společnosti a centrem prodeje zboží. Společnost otevřela faktorie v Kantonu, Pondichéry, na pobřeží Bengálska, Koromandelském a Malabárském pobřeží, v Mocce, Mahé a Isle de France. Rovněž rozmístila dopisovatele do všech přístavů podél námořní cesty do Indie, od Lisabonu do Kantonu.

Ludvík XVI. jmenoval dvanáct ředitelů společnosti. V čele stál Guillaume Sabatier, který byl zároveň jedním z největších akcionářů a posledním správcem společnosti. Dalšími byli Pierre Bernier, Louis-Georges Gougenot, Jacques Dodun, Jean-Francois de Moracin, Etienne Demars mladší, Gourlade, Denis Montessuy starší, Simon Bérard, Jacques Bezard, Augustin-Jacques Perier, a Jean-Jacques Bérard. Povinností ředitelů bylo držet každý pět set akcií po tisíci livrech nebo $20 \%$ kapitálu, Vyhláškou ze září 1786 vzrostlo toto množství na 30 milionů livrů nebo 12000 akcií po 2500 livrech. Reditelé staré společnosti byli postupně bud' vyloučeni, nebo odešli do důchodu. Celou společnost záhy ovládl klan Bérardi̊. V roce 1786 Herries a jeho společníci vytvořili v Paříži silný bankovní dům Boyd, Ker \& Co., což postavení bratří Bérardů ještě upevnilo. ${ }^{32}$

Společnost vystrojila celkem 17 lodí a rychle rostla. Zisky umožnily výplatu dividendy ve výši $18 \%$ v roce 1788 a $16 \%$ v roce 1789 . Během své krátké existence poslala společnost do Indie zboží v hodnotě 36,17 milionu livrů. Šlo převážně o stříbro. Jisté množství kupní síly vzniklo i v Indii vydáváním směnek splatných v Paříži výměnou za rupie. Takové transakce prováděli jak soukromí evropští obchodníci hledající bezpečnou cestu pro své zisky domů, tak soukromé anglické agency houses v Kalkatě a Madrásu, které zajištovaly většinu

30 Clayes, T.-Le Bouëdec, G.: Commerce Libre et Compagnie de Calonne, s. 79.

31 Tarrade, Jean: Le maréchal de Castries et la politique française dans l'Océan Indien à la fin de l'ancien régime. In: Révolution Francaise et Océan Indién, s. 39-48, odkaz s. 45; Haudrére, P.: Quelques aspects, s. 35.

32 Clayes, T.-Le Bouëdec, G.: Commerce Libre et Compagnie de Calonne, s. 79-80. 
soukromého podnikání v těchto městech. Celkové hodnota navrátivšího se množství činila 34,98 milionu livrů, přičemž roční průměr činil přibližně 7 milionů livrů. ${ }^{33}$

Zboží dovezené do Evropy tvořil především textil vyrobený v Čandarnagaru v Bengálsku a v Pondichéry, Jánamu a Káraikkálu na Koromandelském pobřeží. V Mahé na Malabárském pobřeží, kde se společnost snažila nakupovat pepř, zablokovalo jakýkoli pokrok embargo uvalené sultánem Típúem. Obdobně malý úspěch byl zaznamenán v Suratu, odkud společnost plánovala dovážet bavlnu do Evropy pro výrobu na nových strojích $\mathrm{v}$ anglických přádelnách. ${ }^{34}$

Dohoda uzavřená v roce 1787 přiznala Francouzům právo prodávat anglickým faktorům každý rok 200000 maundů $^{35}$ soli a nakupovat od nich18 000 maundů sanytru a 300 bedniček opia. Pokud šlo o textil, nákupy v Bengálsku byly předmětem obvyklých překážek, kterým museli čelit rovněž Nizozemci ze strany gumasthas ${ }^{36}$ Východoindické společnosti. Situace na Koromandelském pobřeží byla oproti tomu uspokojivá. V Pondichéry např. dlouhodobé vztahy s přadláckými komunitami přinášely trvalé zisky. ${ }^{37}$

Od počátku francouzské revoluce byly napadány monopoly všeho druhu jako symboly starého režimu. 3. dubna 1790 Národní shromáždění rozhodlo, že „indický obchod provozovaný za mysem Dobré naděje, je zdarma pro všechny Francouze“, čímž zbavilo společnost jejího monopolu. Tento krok vycházel z předpokladu, že uvolnění obchodu povede k jeho růstu. Opak byl však pravdou. Atmosféra ve Francii nepřispívala k rozvoji soukromého obchodu s Indií. ${ }^{38}$

Na valné hromadě dne 10. dubna akcionáři společnosti jmenovali osm komisařů, jejichž úkolem bylo prozkoumání možností pokračování v činnosti. Byli mezi nimi Dangirard, Monneron (zakladatel běžných účtů) a Sabatier. Dne 23. května, akcionáři rozhodli o obnovení činnosti a jmenovali čtyři komisaře - Delesserta, Fulchirona, Gautiera a Malleta, které pověřili vypracováním stanov nové Společnosti Indií. Kapitál byl snížen na třicet milionů a počet faktorií byl zredukován na sedm: Pondichéry, Jánam, Mahé, Kanton, Surat, Isle de France (dnešní Mauricius) a Isle de Bourbon (Réunion). Liberalizace a revoluce neměla vliv na průběh obchodu společnosti. Lorient si udržel faktický monopol na obchod s východní Indií a společnost nadále vykazovala trvalý růst. Cena akcií dosáhla 1500 liber.

33 Furber, Holden: John Company at Work: study of European expansion in India in the late eighteenth century. Cambrige (Mass.) 1948, s. 17, pozn. 62.

34 Prakash, O.: The New Cambridge History of India II/5, s. 309.

35 Maund - anglicizovaný výraz pro jednotku hmotnosti používanou v britské Indii, Afganistánu, Persii a Arábii. Velikost velmi kolísala podle jednotlivých teritorií. Maund byl ekvivalentem 25 liber (11 kg) i 160 liber $(72,5 \mathrm{~kg})$. V Bengálsku byla míra standardizována v roce 1833 podle místních zvyklostí na 82,28 libry (36 kg). Srv. A New English Dictionary on Historical Principles, Oxford, 1908, s. 250; Prinsep, James: Useful tables, forming an appendix to the Journal of the Asiatic Society: part the first, Coins, weights, and measures of British India ${ }^{2}$. Calcutta, s. 84-90.

36 Gomastha (z perštiny) - označení pro indické agenty Východoindické společnosti, kteří shromažd’ovali zboží od místních tkalců a řemeslníků, stanovovali ceny a podepisovali směnky jejím jménem. Srv. Accounts and Papers of the House of Commons. London 1859, s. 78.

37 Prakash, O: The New Cambridge History of India II/5, s. 309.

38 Haudrére, P.-Le Bouëdec: G.: Les Compagnies, s. 139. 


\section{Britsko-francouzské vztahy v Indii 1787-1792}

30. dubna 1786 byla vikomtem de Soulac a plukovníkem Cathcartem podepsána na Isle de France dočasná konvence o regulaci indického obchodu týkající se jak anglické, tak francouzské společnosti. Protože podmínky konvence nebyly příliš výhodné, Výbor ředitelo̊ anglické Východoindické společnosti napsal Bengálské radě, aby ji nepovažovala za závaznou, nebot' „ustanoveni, která obsahuje, musí upravovat nezbytná pravidla obchodu s Francouzi, nicméně některé části této dohody jsou v rozporu s názory, které jste nám sdělili“. Připravovala se totiž nová dohoda s francouzskou vládou. V této situaci Výbor ředitelů informoval bengálskou radu, že si nepřeje narušit mír mezi oběma národy a ponechal otázku dodržování konvence na uvážení rady. Ta považovala za rozumnější respektovat podmínky konvence až do doby, kdy bude mezi oběma vládami podepsána nová smlouva. ${ }^{39}$

Navzdory této britské vstřícnosti jsou dějiny francouzské společnosti v období guvernérství lorda Charlese Cornwallise (1786-1793) charakterizovány četnými spory s anglickými autoritami o komerční privilegia. Na místě je možno uvést několik př́íladů takových sporů.

Znění konvence ovlivnilo řadu klasických sporů o navrácení zboží. V lednu 1787 bylo obchodní plavidlo plující pod domorodou vlajkou, ale patřící jistému panu Forrestierovi veliteli francouzské kolonie v Mačilípatnamu, které vezlo sůl, zajato Angličany s odůvodněním, že sůl nakoupená Francouzi může být přepravována pouze Evropany. Dříve, než se Forrestier stačil ohradit, byl zatčen, a zboží bylo prodáno ve veřejné aukci. Obrátil se proto na francouzského správce Čandarnagaru Louise C. Dangereuxe, aby podal žalobu o náhradu nákladu u Nejvyššího soudu v Kalkatě. Na základě rozhodnutí soudu byl Forrestier propuštěn a peníze utržené za zboží mu byly zaslány. ${ }^{40}$

V téže době došlo také ke sporu mezi francouzskými obchodníky a anglickými úředníky v celnici v Balalpuru. Francouzští obchodníci byli zatčeni, ale následně násilím osvobozeni francouzskými námořníky. Ukryli se na palubě lodi Lauriston. Britové vše nahlásili Dangereuxovi, aby zjednal nápravu. Ten podal odvážný protest úřadu generálního guvernéra. Problém spočíval v tom, zda Francouzi měli právo trvat na zaměstnávání dělníků, kteří byli již zaměstnáni anglickou společností nebo soukromými obchodníky. Francouzi argumentovali svobodou obchodu, kterou jim udělovaly farmany ${ }^{41}$ Velkých Mughalů. Tyto listiny jim však nedovolovaly požadovat služby pracovníků již zaměstnaných někým jiným. Podle dohod uzavřených v roce 1783 měl britský panovník, přijmout taková opatření „která budou v jeho pravomoci, aby zabezpečil francouzským poddaným, v oné části Indie, jakož $i$ na pobřeži Urísy, Koromandelském a Malabárském pobřeži, bezpečný, svobodný a nezávislý obchod. “42 Francouzi na této bázi žádali rovnost s anglickými obchodníky. Tyto žádosti však vyznívaly

$39 F W I H C$, Vol. XVI, Foreign Letter to Court, 22 January 1787, odst. 3, 4, 5, s. 89-90; Secret Letter to Court, 19 February 1787, s. 108.

40 FWIHC, Vol. XVI, Foreign Letter to Court, 19 February 1787, odst.. 5, s. 110.

41 Farman též firman (pers.) či ferman (tur.) nařízení či dekret vydávaný vládcem (císařem) Mughalské říše. Obdobné listiny vydávali rovněž panovníci Osmanské říše, státu Haidarabád a později panovníci dynastie Páhláví v Íránu. 
naplano, protože byly v rozporu s regulacemi zavedenými správou Východoindické společnosti v Bengálsku, mezi něž patřilo i předkupní právo na indické zboží a monopol na sůl, opium a sanytr. Angličané vystupovali objektivně v roli silnějšího, nutno však říci, že jednali s Francouzi s maximální možnou zdvořilostí a vstřícností a snažili se dodržovat pravidla nedostatečně popsaná mírovými dohodami a prozatímní konvencí. Dangereuxovy žádosti, aby anglické autority, stanovily režim, ve kterém by Francouzi mohli provozovat svůj obchod až do příchodu rozkazů z Evropy, však zůstaly nevyslyšeny. ${ }^{43}$

Britové si naopak stěžovali na rozkazy vydané 31. ledna 1787 Boucherattem, francouzským správcem v Saidábádu, který vysílal své agenty do oblastí výhradní britské působnosti a obracel se dokonce na jejich indické zaměstnance. Britové nicméně i v tomto př́ipadě jednali s Francouzi jako neznalými a požádali Dangereuxe, aby instruoval své podřízené, co mohou, a co nesmějí. Ten „shledal jeho nevhodné jednáni“ a zjednal nápravu. ${ }^{44}$

Další spory vznikly v otázce práva na proces u francouzského nebo anglického soudu, jako v př́ípadě muže jménem LaCosse francouzské národnosti, který však působil ve službách anglické společnosti. Byl obviněn ze zavraždění muže v Dánápuru. Byl zatčen a uvězněn v Čandarnagaru, ale uprchl do nizozemské faktorie v Činsuře, kde byl zatčen na nizozemské lodi a na základě britského zatykače odvezen do Kalkaty a postaven před soud. Dangereux si stěžoval v Pondichéry a žádal, aby byl LaCosse vydán po výslechu do francouzských rukou a „odsouzen, jak má být, pokud bude shledán vinným “. Neopomněl přitom upozornit, že „lidská práva a di̊stojnost francouzského národa nedovoluji, aby poddaný jeho Nejkřestanštějšiho Veličenstva mohl být propuštěn k cizimu soudu, když je možné postavit ho před vlastni soudce. "Kalkatská správa však odmítla LaCosse vydat s celkem logickým odvoláním na skutečnost, že delikvent se dopustil trestného činu v době, kdy byl placeným vojákem anglického 6 . evropského pluku a podléhal tedy britským zákonům. ${ }^{45}$

Vedle těchto velkých případů lze v dokumentech zachytit řadu drobnějších sporů týkajících se zadržování francouzských plavidel. Např. jakési francouzské čluny byly zajaty v Baranagaru, které vezly sanytr. Protože zaplatily clo v Kalkatě, byly nedlouho poté propuštěny. ${ }^{46}$

Četné byly rovněž stížnosti a proti stížnosti týkající se překážek kladených francouzskému obchodu v několika oblastech ze strany zaměstnanců anglické společnosti, stejně jako nelegální činnosti francouzských agentů v jiných bengálských provinciích. Mnohé vyplývaly prostě z konkurenčního zápasu na bengálském trhu. V roce 1788 bylo např̀. Francouzům povoleno nakoupit jen dvě stě bedniček s opiem. Proti tomu protestoval francouzské komerční rezident v Sylhatu, protože měl v úmyslu zásobovat tímto produktem armády horských rádžů. Výběrčí daní v Sylhatu byl proto instruován, aby podnikl okamžitou akci směřující k zastavení obdobných transakcí. ${ }^{47}$

V záŕí 1787 pak nastoupil Thomas hrabě de Conway na post generálního guvernéra francouzských osad v Indii (jmenován do této funkce byl již 9. března 1787). Conway pro-

43 FWIHC, Vol. XVI, Foreign Letter to Court, 22 January 1787, s. 90-95; Political letter to Court, 5 March 1787, odst. 3, s. 112-113.

44 FWIHC, Vol. XVI, tamtéž odst. 3-4; Political letter to Court, 5 March 1787, odst. 2, s. 112.

45 FWIHC, Vol. XVI, Foreign Letter to Court, 19 February 1787, odst. 2, s. 109-110.

46 FWIHC, Vol. XVI, Secret Letter to Court, 12 January 1788, odst. 24-25, s. 174.

47 FWIHC, Vol. XVI, Secret Letter to Court, 6 November 1788, odst. 82-83, s. 199. 
sazoval přátelský přístup vưči Angličanům a vyjádřil se pro zachování podmínek obchodní konvence, především těch, které se týkaly opia a sanytru. ${ }^{48} 21$. května 1788 obdržela Bengálská rada z Anglie novou konvenci podepsanou zástupci vlád ve Francii a Anglii vysvětlující 13. článek mírové smlouvy. Různé články této konvence byly přesto dále promýšleny a Výboru ředitelů Východoindické společnosti byla sdělována nejrůznější pozorování a náměty týkající se vzájemného obchodu ${ }^{49}$

V listopadu 1786 vystřídal Dangereuxe na postu guvernéra Čandarnagaru Benoît Mottet de La Fontaine a koncem roku 1788 François Emmanuel Dehaies řečený de Montigny, bývalý francouzský rezident na dvoře navábů v Púně. De Montigny si kladl za cíl nejen obnovu francouzského obchodu v Bengálsku, ale i zvýšení výběru daní a administrativní reformy. Jakkoli to byl čestný a energický člověk, jeho uspěchaný a nadšený přístup zkřížil zájmy mnoha místních obyvatel. Týkalo se to jak personálních výměn na řadě postů, tak prohlášení obchodu s opiem a solí za předmět francouzského státního monopolu. Problémem bylo i nejasné administrativní postavení francouzské kolonie v Čandarnagaru, která sice formálně podléhala dozoru z Pondichéry, neexistovaly však žádné účinné nástroje tohoto dohledu a guvernér přímo závisel na francouzském generálním guvernérovi na Isle de France. De Montigny jako oblíbenec Conwaye byl tedy na místě vnímán jako svého druhu vetřelec. ${ }^{50}$

Situace se začala měnit pod vlivem revoluce ve Francii. Zprávy o začátku revoluce přivezla do Bengálska lod' Bienvenue v únoru 1790. Britové do půl roku zachytili zprávu o revoltě v Čandarnagaru. Plukovník Bie, dánský guvernér Serampuru referoval, že 3. září 1790 ve čtyři hodiny ráno povstalci obklíčili rezidenci plukovníka de Montignyho v jeho venkovském sídle v Goréty ${ }^{51}$ a zajali ho spolu s dalšími vyššími úředníky. Vzbouřenci vytvořili ze svých řad generální shromáždění občanů a národní výbor pro kontrolu činnosti guvernéra, „kterého dlouhý pobyt na maráthském dvoře naučil všem zpưsobům hrubé politiky“ a „který věrill, že může podobně postupovat při správě Čandarnagaru. " "52

Vzbouřenci v Čandarnagaru zvolili provinční radu, která sesadila guvernéra a požádala o potvrzení tohoto aktu Vrchní radu v Pondichéry. Revolucionáři rovněž vyjádřili úmysl „násilně presunout z Činsury francouzské šlechtice, kteř́ tam nalezli útočiště“. Velitel této nizozemské bengálské kolonie Isaac Titsingh proto ihned požádal Angličany o pomoc „aby zabránil realizaci této hrozby “. Britové nezaváhali. Tři prapory sipáhíu vyrazily z Bárákpuru ke Goréty. Přestože francouzská revoluční posádka mezitím porušila mírovou dohodu

48 FWIHC, Vol. XVI, Secret Letter to Court, 14 December 1787, odst. 42-43, s. 166.

49 FWIHC, Vol. XVI, Secret Letter to Court, 6 November 1788, odst. 62-79, s. 197-199.

50 Sen, S. P.: The French in India (1765-1816), s. 455-456.

51 Goretty (též Ghyretty) - malé město v Bengálsku ležící na břehu řeky Huglí, na silnici ze Serampuru do Čandarnagaru. Byla zde venkovská rezidence guvernéru Čandarnagaru známá také jako „francouzská zahrada“. Srv. Hamilton, Walter: The East Indian gazetteer: containing particular descriptions of the empires, kingdoms, principalities, provinces, cities, towns, districts, fortresses, harbours, rivers, lakes, Eंc. of Hindostan, and the adjacent countries, India beyond the Ganges, and the Eastern archipelago; together with sketches of the manners, customs, institutions, agriculture, commerce, manufactures, revenues, population, castes, religion, history, $\mathcal{G}^{2} c$. of their various inhabitants. Vol. 1. London 1828, s. 578.

52 Citováno ze stížnosti občanů sepsané revolucionáři v Čandarnagaru 19. června 1790. Srv. Sen S. P.: The French in India (1765-1816), s. 455. 
opevňováním osady a rozmistováním artilerie na hradby, Britové v obavě o životy zajatců postupovali mimořádně opatrně. Prostřednictvím primátora města doručili revolučnímu výboru několik deklarací a propozic britské vlády. Čandarnagarský výbor francouzských občanů jim nicméně sdělil své „rozhodnuti ihned popravit plukovnika Montignyho, pokud britské jednotky vytáhnou $k$ Čandarnagaru “. Angličané ve snaze získat čas nabídli povstalcům jistá privilegia v obchodu se solí. ${ }^{53}$

Revoluce v Čandarnagaru prošla od května do října 1790 složitým vývojem, jehož výsledkem bylo postupné odcizování této kolonie nadřízeným v Pondichéry. Když v říjnu 1790 dorazily do Čandarnagaru informace o tom, že hrabě de Conway sesadil de Montignyho z funkce a nahradil ho Mottetem : „část obyvatel Čandarnagaru, která byla v opozici vůči těm, kteři zůstali na straně plukovnika de Montigny, legálního velitele, naložila na palubu malého plavidla některé z vězňư, které zadrželi v Goréty, se záměrem je poslat na ostrov Isle de France“. Povstalci netušili, že Britové zavedli přísnou kontrolu všech plavidel plujících po řece Huglí. Malý francouzský škuner Patriote s uprchlíky se tak 19. ř́ijna musel zdát kapitánovi Apsleymu, správci Diamantového přístavu (též Hadžípur) na východním břehu řeky Huglí (dnes jižní předměstí Kalkaty). Plukovník Montigny a tři jeho druhové, kteří byli na palubě tohoto plavidla, tak byli osvobozeni, ale „čtyři dalši Francouzi, kteři byli zajati při stejné př́ležitosti a kteř́ byli rovněž na palubě, byli kapitánem Apsleym ponecháni na lodi, nebot’ deklarovali, že si nepřeji vystoupit na břeh “. Mezi zajatci francouzského revolučního výboru tedy zjevně panovaly názorové rozdíly. Britové o celé věci informovali guvernéra de Conweye. ${ }^{54}$ Motteta povstalci nejprve vyslýchali „téměr jako kriminálnika“ a následně omezili jeho pravomoci takovým způsobem, že raději dobrovolně odešel do Kalkaty. Bylo mu zde dovoleno zůstat, dokud francouzský král nerozhodně, jak budou problémy v kolonii řešeny..$^{55}$

V roce 1790 bylo Francouzi dovezeno více soli, než kolik povolovala konvence. Britové proto přijali opatření k zabránění pašování soli. Povolení k dovozu soli mělo být vydáno maximálně pro 100 obchodníků. Tato povolení musela být podepsána tajemníkem bengálské vlády ve Fort William a registrována v číselném pořadí kontrolorem výroby soli. Lodě vezoucí sůl měly podléhat kontrole u mola společnosti v Kalkatě. Tato regulace byla sdělena francouzské vládě v Pondichéry, jakož i panu Mottetovi. Francouzi nicméně toto opatření porušovali. Následovaly proto konfiskace a po nich francouzské protesty. ${ }^{56}$

Počátkem roku 1791 hrabě de Conway těžce onemocněl a odplul proto na Isle de France. Plukovník de Canaple byl záhy poté jmenován „velitelem záležitostí francouzského národa“ v Čandarnagaru. Tento francouzský agent se ani neodvážil do Čandarnagaru. Zůstal v Kalkatě, kde jej uznalo vedení prezidencie, a soustředil se na otázky obchodu. Usiloval o to, aby př́írůstek importované soli byl přesunut do účtů v novém roce. Množství, o které se jednalo, odpovídalo výši ilegálních transakcí a požadavek byl proto odmítnut. Plukovník de Canaple byl proto objektem pohrdavých útoků v kalkatském tisku. Vydavatel

53 FWIHC, Vol. XVI, Foreign Letter to Court, 17 November 1790, odst. 5-11-22, s. 329.

54 FWIHC, Vol. XVI, Foreign Letter to Court, 17 November 1790, odst. 2-22, s. 328-331.

55 Tamtéž, odst. 28, s. 332; FWIHC, Vol. XVI, Foreign Letter to Court, 31 January 1791, odst. 4 a 5 , s. 365.

56 Tamtéž, odst. 7-14, s. 365-366. 
novin byl však vedením prezidencie instruován k zmírnění tónu. Jiným požadavkům však Britové vyhověli. Jistý pan Lausan, zaměstnanec francouzské společnosti, žádal o výjimku ze cla na zboží, dovezené na lodi La Bretagne, a část tohoto požadavku byla splněna. ${ }^{57}$

$\mathrm{V}$ polovině roku byla regulace týkající se importu soli upravena tak, aby uklidnila Francouze. Na žádost plukovníka de Canaple byly francouzským lodím v Kalkatě přiděleny koncese. Veškerá sůl i další zboží bylo soustředěno v Kalkatě, aby měli Angličané situaci pod kontrolou. Francouzům zde bylo dovoleno nakládat zboží do stanovené výše bez jakéhokoli placení poplatků. ${ }^{58}$

Počátkem dubna 1791 byla na řece Huglí v Diamond Harbour zadržena francouzská lod' s 30 otroky na palubě. Plukovník de Canaple byl požádán, aby provedl jejich osvobození. Této žádosti de Canaple vyhověl. Panu Georgovi Wheatleymu byla dokonce v souladu s proklamací z 22. července 1789 potvrzena náhrada 1200 rupií za objevení a osvobození těchto otroků..$^{59}$

Když plukovník Canaple 5. srpna 1791 zemřel, angličtí důstojníci byli posláni, aby jej na znamení úcty doprovodili na poslední cestě. Guvernér francouzských osad východně od mysu Dobré naděje David Charpentier de Cossigny poté jmenoval pány Gautiera a Yuvona jako komisaře francouzského krále pověřené uspořádáním záležitostí v Čandarnagaru, kde byla situace i nadále velmi rozbouřená. V těchto funkcích je uznala i anglická Východoindická společnost. Jak se však později zjistilo, Camille Charles Leclerc, rytîr de Fresne, guvernér Pondichéry, který byl dobře informován o zhoršujícím se de Canaplově zdravotním stavu, ale špatně informován o rozkazech pana de Cossignyho, poslal pana Fumerona (též Fumerrona), aby převzal velení v Čandarnagaru. Mezi jmenovanými guvernéry záhy propukl spor o kompetence. Všichni komisaři navíc požadovali od Angličanů tři sta bedniček s opiem, každoroční francouzský podíl francouzské společnosti v Bengálsku. Bengálská rada po jistém váhání raději korespondovala s Fumeronem, nebot’ pan de Fresne „uznal pana Charpentiera za svého nadřízeného, avšak v tomto př́padě bylo rozhodnutí jen na něm, nebot’ pan Charpentier má dohližet na účty transakci všech francouzských osad v Indii“. Bedničky s opiem, stejně jako majetek plukovníka de Canapla byly tedy předány Fumeronovi. ${ }^{60}$

Britové zůstávali v písemném styku i s de Fresnem, který je např. dopisem z 20. srpna 1791 informoval o změně francouzské státní vlajky a žádal je o rozšíření této informace v místním britském tisku. ${ }^{61}$

V roce 1792 Francie požádala anglickou Východoindickou společnost o udělení povolení exportovat obilí z Bengálska do Pondichéry a na Mauritius. Obě kolonie totiž trpěly jeho nedostatkem. Anglická Východoindická společnost vydala nezbytné privilegium pro Pondichéry. Zde vycházela z informací, podle nichž maisúrský sultán Típú vpadnul do Karnátaku a okolí města ohrožovala jeho jízda, „což donutilo velký počet obyvatel této

57 FWIHC, Vol. XVI, Foreign Letter to Court, 17 March 1791, odst. 2, 6, 10, s. 367-369.

58 FWIHC, Vol. XVI, Foreign Letter to Court, 17 August 1791, odst. 2-9, s. 399-401.

59 Tamtéž, odst. 20-24, s. 401.

60 Tamtéż, odst. 29, s. 404; FWIHC, Vol. XVI, Foreign Letter to Court, 25 November 1791, odst. 14-27, s. $408-410$.

61 Tamtéž, odst. 21, s. 409. 
země hledat dočasnou ochranu za francouzskými hradbami“. Potraviny tedy nebylo možno zajistit jiným způsobem. Požadavek týkající se Mauricia byl však zamítnut s poukazem na skutečnost, že „potřeby našich vlastnich provincii nás nutí uvalit embargo. "62

6. listopadu 1792 generální shromáždění v Čandarnagaru vyhlásilo ústavu, která mj. deklarovala nezávislost kolonie na Pondichéry, formálně se nicméně odvolávala na autoritu (v té době již sesazeného) francouzského krále. V kolonii panoval chaos. Fumeron byl odvolán a generální guvernér jmenoval další komisaře, L'Escalliera a de Morina. Jménem francouzské republiky, tak chtělo mluvit hned několik osob. ${ }^{63}$

Britové tento vývoj ignorovali. $\mathrm{V}$ britské korespondenci z tohoto období lze nalézt stále především zprávy o konfiskaci soli dovezené Francouzi do Bengálska v letech 1790$1791^{64}$ a ceně jednotlivých zásilek sanytru dodávaných Francouzům. ${ }^{65}$ Jednotlivě se objevují informace o francouzském požadavku na zadržování dezertérů z francouzských lodí. Zmíněn je rovněž soudní proces u Nejvyššího soudu v Kalkatě vedený proti velitelům francouzských lodí na základě žalob podaných jednotlivými francouzskými námořníky. ${ }^{66}$

\section{Válka mezi Británií, Francií a Nizozemskem}

Válka, kterou Francie vyhlásila Spojenému království a Nizozemsku, byla zahájena 1. února 1793, a zprávy o ní pronikly do Indie prostřednictvím Baldwina, britského konzula v Alexandrii, 1. června 1793. Přestože nikdo neobdržel nějaké oficiální vyrozumění, Rada ve Fort William se rozhodla vydat „rozkazy, které byly neprodleně provedeny, o obsazen Čandarnagaru, a několika francouzských kolonii v této zemi “. Nepř́tele se podařilo zaskočit. Čandarnagar v Bengálsku se vzdal bez boje již 11. června praporu sipáhiů z Bárákpuru pod vedením majora Duncana. ${ }^{67}$

Vláda v Madrásu současně vypravila ihned fregatu Minerva, která s ozbrojenými obchodními loděmi Royal Charlotte, Warley a Triton zajistila námořní blokádu Pondichéry. Současně byl vyslán oddíl pod vedením plukovníka Johna Floyda, který záhy město oblehl. Francouzská posádka v Pondichéry stačila opravit pobořená opevnění a dopravit do města zásoby zaslané z Maskarén, počet vojáků zde však nepřesahoval tisíc mužů a doplňování vojska vázlo. ${ }^{68}$ Angličané město obklíčili ve dnech 12. až 15. července 1793. Obležení velel výkonný velitel madráské armády, generál John Braithwaite. Disponoval 24000 vojáky, z toho 6000 Evropany, a těžkým dělostřelectvem. Jedinou nadějí pro obležené

62 FWIHC, Vol. XVII, Foreign Letter to Court, 25 January 1792, odst. 4-5, s. 149-150; 8 April 1792, odst. 2-3, s. 150-151.

63 FWIHC, Vol. XVII, Foreign Letter to Court, 25 January 1792, odst. 2, s. 149; 8 April 1792, odst. 11, s. 152 and 12 December 1792, odst. 10, s. 156.

64 FWIHC, Vol. XVII, Foreign Letter to Court, 12 December 1792, odst. 4, s. 155.

65 FWIHC, Vol. XVII, Foreign Letter to Court, 8 April 1792, odst. 4-9, s. 151-152; 1 September 1792, odst. 2-4, s. 154 .

66 FWIHC, Vol. XVII, Foreign Letter to Court, 12 December 1792, odst. 12, s. 156.

67 FWIHC, Vol. XVII, Political Letter to Court, 13 August 1793, odst. 101, s. 294.

68 FWIHC, Vol. XVII, Political Letter to Court, 1 August 1793, odst. 5-9, s. 274. 
bylo námořnictvo. Přestože Francouzi v té době disponovali na moři převahou, neodvážili se blokádu prorazit a omezili se na výzvědnou činnost týkající se počtu anglických lodí v oblasti. Po několikadenním obležení Britové nabídli 3. srpna kapitulaci, kterou místní Národní shromáždění odmítlo, mj. povzbuzeno zprávami o vítězství u Valmy v Evropě. Následovalo bombardování doprovázené rozhazováním letáků s portrétem Ludvíka XVI. a nápisem „Zemřel jsem nevinny““. ${ }^{69}$ Pod dojmem těchto událostí a nepříznivých zpráv z domova se plukovník August Chermont velící obraně města rozhodl 23. srpna vzdát. ${ }^{70}$ Bez boje se v průběhu srpna vzdaly i Jánam na Koromandelském pobřežî ${ }^{11}$ a Mahé na Malabárském pobřeží. ${ }^{72}$

23. října 1793 Výbor ředitelů anglické Východoindické společnosti instruoval bengálskou vládu, aby do dubna 1794 připravila 5000 mužů evropské pěchoty, 300 evropských dělostřelců, 1000 lascarů $^{73}$ a dva prapory sipáhiơ ${ }^{74}$. Sir William Medows a plukovník James Stuart byli jmenováni do čela expedičního sboru, který měl obsadit i francouzské ostrovy Isle de France (Mauritius) a Isle de Bourbon (Reunion), odkud operovali francouzští korzáři a způsobovali Východoindické společnosti nemalé ztráty. Jmenování Medowse bylo však později zrušeno. ${ }^{75}$

Instrukce Výboru ředitelo̊ dorazily do Kalkaty 4. května 1794. Ve své odpovědi z 15. května 1794 Rada ve Fort William podala detailní zprávu o vojenské a politické situaci v zemi a vyjádřila jednoznačný názor, že bez podstatných posil z Evropy, nebude možné expedici podniknout. Konstatovala: „Výkonný velitel nepochybuje o tom, že nedostoji svým povinnostem, v čemž s ním rada souhlasi, nebot' mírový stav indické armády, $i$ za předpokladu kompletnosti, neni dostatečný $k$ ochraně držav společnosti, a protože je nyni snižen $v$ praxi o třetinu, a dalši redukce evropské pěchoty, v rozsahu navrhované tajným výborem nebo plukovnikem Stuartem, by znamenala bezprostředni nebezpeči. "S odvoláním na politickou situaci konstatovala, že bezpečnost dominií společnosti v Indii závisí zcela na jejích vlastních silách a schopnosti je udržet. Skepticky se proto vyjádřili o myšlence začlenění indických sil do britské aliance. ${ }^{76}$ John Shore, generální guvernér britské Indie (1792-1793) v osobním dopise Henrymu Dundasovi, předsedovi kontrolního výboru Východoindické společnosti z 12. června 1794 navíc vyjádřil své pochybnosti o schopnostech důstojníků společnosti, pokud jde o vedení války, a konstatoval, že to rovněž ovlivnilo jeho rozhodnutí. ${ }^{77}$

69 Sen S. P.: The French in India s. 447-449.

70 FWIHC, Vol. XVII, Political Letter to Court, 28 October 1793, odst. 6-9, s. 296.

71 FWIHC, Vol. XVII, Political Letter to Court, 1 August 1793, odst. 29, s. 274.

72 FWIHC, Vol. XVII, Political Letter to Court, 28 October 1793, odst. 15, s. 298.

73 Lascarové - domorodí námořníci nebo námořní pěchota z jižní Asie ve službách východoindických společností.

74 Sipáhiové - indičtí domorodí vojáci, kteří prodělali evropský výcvik a sloužili některé z evropských východoindických společností.

75 FWIHC, Vol. XVII, Secret Letter to Court, 21 March 1794, odst. 2, s. 131.

76 FWIHC, Vol. XVII, Secret Letter to Court, 15 May 1794, odst. 3, s. 465.

77 Furber, Holden: The Private Record of an Indian Governor-Generalship : the Correpondence of Sir John Shore, Governor General, with Henry Dundas, President of the Board of Control, 1793-98. Cambridge 1933, s. 55. 
V téže době Výbor ředitelů Východoindické společnosti rozhodl, že válečné lodě, které měly být vyslány z Anglie, nebudou vypraveny, nebot̉ nechtěli, aby byla plavidla společnosti použita pro expedici na Maskarény. 21. března 1794 již ředitelé nařídili Bengálské vládě, aby expedici odložila a potvrdila tyto instrukce. ${ }^{78}$

Př́ípravy expedice v Indii nicméně pokračovaly. ${ }^{79}$ Britské vláda vyslala pana de Grand Pré „talentovaného francouzského di̊stojnika s množstvím mistnich informaci", aby pomohl autoritám v Indii, ${ }^{80}$ ale informace, které poskytoval, a názory, které vyjadřoval, nebyly shledány dostatečné, aby oprávnily změnu původního hodnocení týkajícího se velikosti jednotek nutných pro realizaci akce. Panu de Grand Pré byl proto umožněn návrat do Anglie.$^{81}$ Myšlenka na obsazení Maskarén byla nakonec v lednu 1795 opuštěna, dokud nebude zajištěna bezpečnost indických držav společnosti. ${ }^{82}$

\section{Likvidace Společnosti pro Indie a Čínu}

Britský úspěch při obsazení francouzských držav v Indii byl nepochybně podmíněn rozpory mezi mocenskými skupinami uvnitř francouzských kolonií a paralyzováním Společnosti pro Indie a Čínu ze strany konventu. Snahy akcionářů společnosti směřovaly k uchování východoindického obchodu v nových podmínkách, v obecné atmosféře nedůvěry všech proti všem však vedly k jedinému. Společnost upadla do podezření z kontrarevoluční činnosti proklamované Výborem veřejného blaha a Výborem veřejné bezpečnosti. Konvent proto rozhodl 26. července 1793 o zapečetění jejích budov. Druhý dekret ze dne 27. srpna 1793 zrušil Společnost pro Indie a Č́nu a zabavil zboží a lodě. Hodnota zabaveného majetku byla odhadnuta na 28 milionů livrů. Akcionáři se snažili zabránit zdanění dividend, které bylo uvaleno v srpnu 1792 tím, že společnost sami zlikvidují. Jeden z akcionářů, bývalý kapucín Chabot se pokusil ovlivnit úředníky 100000 livry, aby změnili v tomto smyslu znění likvidační dekretu. Tento triviální pokus o úplatek byl ale interpretován jako kontrarevoluční činnost. 18. března 1794 bylo uvězněno 9 ředitelů společnosti. Tři byli gilotinováni. Mnozí významní podílníci společnosti byli rovněž gilotinováni. Postupně až do 10. thermidoru 2. roku republiky (28. července 1794) je postupně následovali hébertisté, dantonisté a robespierristé v řadách společnosti. Augustin-Jacques Perier spáchal v roce 1793 sebevraždu. Část akcionářủ unikla smrti tím, že byli internováni jako duševně nemocní v pečovatelském domě Jacquese Belhomma na doporučení Jeana-Jacquese-Régise Cambacérèse, člena Výboru veřejné bezpečnosti. Všichni podílníci společnosti museli nahlásit všechny pohledávky $\mathrm{v}$ „neutrálních zemich“ a „neprátelských zemich“. 83

FWIHC, Vol. XVII, Secret from Court, 21 March 1794; 8 April 1794, s. 130-132.

FWIHC, Vol. XVII, Secret Letter to Court, 31 May 1794, s. 475-476.

81 FWIHC, Vol. XVII, Secret Letter to Court, 31 January 1795, odst. 6-9, s. 487-488.

82 FWIHC, Vol. XVII, Secret Letter from Court, 14 June 1795, odst. 1-2, s. 134. 
Po 9. thermidoru se Cambacérès stal předsedou výboru veřejného blaha a ředitele společnosti osvobodil. Vedení společnosti se znovu ustavilo byṫ v redukované podobě. 30. května 1795, byla vytvořena patnáctičlenná deputace, včetně Lecouteulxe, Audiberta, Devaisnese, Malleta a Moreaua, která byla vyslána do konventu, aby požadovala vrácení zabaveného majetku společnosti odhadovaného ještě 6. prosince 1793 na 28544000 livrů. V červenci 1795 jim bylo uděleno slyšení a společnosti byly vráceny tři lodě. Společnost pro Indie a Č́nu však již nemohla být obnovena a zahájit obchodní činnost, Akcionáři proto sami rozhodli o její likvidaci. Poslední rozvahy jejích agentů v Bengálsku jsou zaznamenány v záŕí $1795 .{ }^{84} \mathrm{~V}$ témže roce byly pohledávky státu zaneseny do Velké knihy veřejného dluhu. Komisaři-likvidátoři Mallet, Martin André a Jean Baptiste Rodier byli odhodláni získat náhradu za majetkové ztráty z roku 1793 a zahájili proto soudní ŕízení proti státu, který skončilo až v roce $1875 .{ }^{85}$

\section{Závěr}

Z výše uvedené analýzy je patrné, že v sledovaném období lze vymezit dvě zcela protichůdné etapy britsko-francouzských vztahů v Indii. V období administrativy generálního guvernéra Cornwallise (1786-1792) byly anglicko-francouzské vztahy v Bengálsku, ale i v celé Indii vcelku prrátelské, jakkoli Francouzi již vystupovali v Indii jako slabší partner. Britové se zajímali především o obchod. Pečlivě sledovali vliv revolučních událostí na dění ve francouzských osadách, nijak však do nich nezasahovali, pokud o to nebyli požádáni zástupci jiné evropské země. Snažili se jednat s francouzskými zástupci s oficiálním pověřením, ale vývoj událostí je v tomto ohledu stavěl do neřešitelných situací. Nejrůznější spory a stížnosti, ke kterým se upínala největší pozornost obou východoindických společností, však byly řešeny poměrně snadno, protože obě strany měly zájem na udržení přátelských vztahů a výnosného obchodu.

Zásadní změnu přineslo francouzské vyhlášení války Británii a Nizozemsku, které však Francii nepřineslo nic jiného než ztrátu významných obchodních kolonií. Pohotová reakce Britů dokázala předejít francouzským akcím v oblasti a získat kontrolu nad jejich državami. Britové si však byli vědomi svých omezených možností, kriticky hodnotili rozsah i kvalitu vlastních sil. Navzdory potížím, které jim způsobovaly akce francouzských korzárů operujících ze základen na Maskarénách, se nenechali vyprovokovat k akci proti těmto ostrovům. Minimální vůli k obraně na straně francouzských sil v oblasti lze připsat na vrub nezájmu revoluční Francie o dění v koloniích, sociálním rozporům, které do francouzských osad přinesla francouzská revoluce, a v neposlední řadě oslabení a posléze zánik mimořádně úspěšné Společnosti pro Indie a Č́nu, obchodního tělesa, na jehož fungování zcela závisel ekonomický život i obranyschopnost francouzských faktorií $\mathrm{v}$ této části světa.

84 Tamtêż, s. 83.

85 Morineau, M.: Les Grandes Compagnies des Indes orientales, s. 105. 


\section{Anglo-French Relations in India 1787-1794 in the Mirror of Governor-Generals of British India Sources}

The study deals with the British-French relationships in India in the French Revolution period. First, the author summarizes subjects covering this area, which have been investigated in historiography so far, next he refers to unused sources from the Office of Governor-General of Fort William Presidency in Calcutta, finally, he tries to reconstruct the British-French relationships in that area, and defines two antagonistic stages.

Relationships between the English and the French were friendly in the period of GovernorGeneral Cornwallis's administration (1786-1792), anyhow the French had appeared to be a weaker partner. The British were mostly interested in trade. They had been carefully watching the impact of those revolutionary events in French settlements, but nowise interfered unless they had been asked by other European countries representatives. They tried to negotiate with French representatives having official authorisation, nevertheless would be placed in catch-22 situations due to the course of revolutionary events. Numerous disputes and complaints both East-India companies had devoted considerable attention were solved rather easily since both parties were interested in maintaining friendly relationships and profitable trade.

A turning point came when the French declared war against Great Britain and the Netherlands, which, however, would bring France nothing but the loss of important trading colonies. Britons' prompt reaction helped prevent French actions in the area and get control over their dependencies. However, critically assessing extent and quality of their power, Britons were aware of their limited possibilities. Despite difficulties caused by actions performed by French corsairs operating from bases on the Mascarene Islands, they did not let themselves drag in actions against these Islands. Minimum will of the French power in India to defend themselves might be attributed to the lack of interest revolutionary France showed in events in colonies, social variances brought to French settlements by the French Revolution, but also the twilight and death of extraordinary successful Company for Indies and China, a trading body, on whose functioning the economic life and defensiveness of French factories in this part of the world had been completely dependent. 